\title{
164. 振子様回転刺激の視運動性眼振に対する影響
}

\section{藤川憲夫・北原正章（滋賀医大）}

迷路は頭部運動に際し外界に固定または移動する事 物を明確に foveaで捕らえるために存在すると考え られている。今回我々は, 視運動性眼振に振子様回転 刺激を加えてその影響を検討した。

対象は, 耳疾患平衡障害のない28歳から35歳までの 健康な男性 7 名である。

方法は，任意の周波数速度で作動する振子様回転椅 子に座った被験者の眼の前に，椅子と同じ動きをする 半円筒形のスクリーンを備え，その内側に被験者に対 して椅子の回転と無関係伅常に一定速度の視刺激を与 えられる装置を用いた。視運動性眼振は被験者に対し て角速度 $30^{\circ} / \mathrm{sec}$ と $90^{\circ} / \mathrm{sec} て ゙$ 右回転, 左回転について 行った。振子梯回転刺激住, 周波数 $0.1 \mathrm{~Hz}$, 最大角速 度 $30^{\circ} / \mathrm{sec}$ である. 記録は眼球運動の水平成分のみ DC 記録を行った。視運動性眼振の緩徐相速度を求好振子 様回転刺激を加えないときと加えたときを比較した。 視運動性眼振の刺激速度を入力とし眼振緩徐相速度を 出力とし出力を入力で除したものを outoput rate した。

視刺激が $90^{\circ} / \mathrm{sec} の$ 場合, 迷路刺激と視運動性眼振 が協調して作用する時outoput rateはほぼ 1 に近く
なった．迷路刺激と視運動性眼振が非協調して作用す る時 rate は0.24と小さくなった。協調の phaseは，椅 子が視刺激と反対方向に回転し始好る点上り遅れて始 まり，同方向に回転し始める点より早く終了した。視 刺激が $30^{\circ} / \sec$ の場合, 協調する時, 非協調の時, 共に rate はほほ 1 の付近にあり，協調と非協調の作用に差 は見られなかった。協調，非協調の phase 峙，椅子の 回転方向が変わる点で始まり終了した．協調する場合 は，迷路刺激が加わり rateが 1 となる。しかし 1 を越 交ないのは視刺激に対する固視機能と眼球を中心に房 す作用が働くからと考える。非協調の場合固視と反対 方向に眼球を中心に戻す作用が働き迷路刺激による眼 球変位作用を強くするため rateが小さくなったと考 之る.協調効果は，視刺激が速い場合外界の刺激と反 対方向の停止前に消失するが, 頭部運動の停止と外界 事象の停止により速や加に迷路刺激効果を消失させる のに役立つと考之る。㰓問 小林英人(富山医菜 大).一側性の前庭機能障害ではどのような結果が予湘 されるか。応答 一側あるいは両側前庭障害につ いては今後検討する予定である。

\section{5.ファジー理論を用いた視運動性眼振パターンの診断}

\section{千葉恭久・古屋信彦（帝京大）}

人間が行うパターン諗識をコンピュータで実行する ことは比較的困難である。しかも，もしコンピュータ によるパターン認識が実現できれば，病気の自動診断 も可能になり，医師の診断の支援が可能になると考え られる.今回われわれは視運動性眼振の眼振パターン をコンピュータで診断するシステムの理論構築を行っ た.

万法 コンピュータが行う視運動性眼振パターン (OKP) の診断は, めまい平衡機能の尃門家が行う OKP 診断と診断結果が一致するような理論構成とし た。また、コンピュータによる診断への入力は，視運 動性眼振の解析結果, 寸なわち, 総眼振数, 総緩徐相 振幅, 総緩徐相速度, 平均急速相速度, 視運動性眼振 追跡限界およびそのときのドラムスピードとした。こ 机らの変数および専門家の正常・異常の診断はファジ 一集合をなしファジー理論が適応できることが判明し た。そこでファジー推論を用いて OKPの正常・異常が 診断できる推論規則を 6 種類設定した，最終的なコン ピュータ診断の結果は，マンダニが提唱する重心法を 用いて推論規則の結果を合成することで決定した。

結果 尃門家のパターン診断によって正常と殓断さ
れた30名と異常と診断された22名に推諭規則を適応さ せたところ，専門家が正常と診断したパターンのうち 推論結果でも正常と判定できたのは29名, 異常と診断 したパターンのうち推論結果でも異常と判定できたの は21名であった。すなわち，推論規則の結果と尃門家 の視運動性眼振のパターン診断との一致率は $96 \%$ \%て った。また，同じ専門家が行った251名の視運動性眼振 のパターン診断の結果を用いて，推論規則による診断 の再現性を検討した。専門家の診断と推論結果との一 致率は，共に正常であったもの $97 \%$ ，共に異常であつ たもの78\%，共に境界型であったもの $25 \%$ あ゙あった。 また総合した一致率は87.3\%であった。この結果より， 今回設定した推論規則を用いれば，専門家による視運 動性眼振の診断を再現できることが判明し，眼振解析 結果を用いたコンピュータ診断が可能であると考えら 枕た。質問 島田信吾 (東京)。異常者と判断した 中に中枢と末梢の割合はどの程度あったか。応答 今回の報告は，専門家の診断をコンピュータでシュミ レートするのが目的であり，異常例では，中枢性末梢 性の区別は検討していない。頃問 時田喬(岥阜 市民). OKP 自動診断するより, OKN の生理学的パ 
ラメータを質的，量的に捉えて判定すれば，専門家の 判定を基準とせず客観的な判定ができるのではない か. 応答 OKP の正常值に関してはすでに報告し てある. 正常值を設定してもパターンの正常・異常は
決められないし，多変壆解析を行っても診断率は高く ない. 応答 コンピュータを用いて診断できるこ とが医者の診断の補助となると考え，それを可能なら しめるシステムの発表を行った。

\title{
166. 刺激形式の差異による視運動性眼振 $(\mathrm{OKN})$ 急速相の反応態度
}

\author{
渡辺行雄・大村明彦・将積日出夫 - 伊東宗治 - 水越鉄理（富山医楽大）
}

目的 前庭性眼振の眼振急速相は緩徐相による眼球 偏位を向中心性に補正する反射的な眼運動と考えられ るが，視運動性眼振 (以下 OKN) の場合は眼球偏位の 補正と視標捕捉による㣫動性眼運動の2つの要素が関 与している。今回，私達は現在ルーキンに採用されて いる OKN 刺澈法の線条剌激と, 視野全体が刺激され るランダム剌激による OKN について，とくに急速相 に関与する視標捕捉と眼球偏位を補正する反射的な要 素について検討した。

方法 半径 $75 \mathrm{~cm}$ の半円球型スクリーンに線条視標 は30度間隔で視角 2 度の線条を，ランダム視標は直径 5 20mmの無数の小円を視野全体に不規則に投影し た。視嗱動制激は等加速度刺激とし, 加速度 $1 \% \sec ^{2} て ゙$ 100 秒間 $100^{\circ} / \mathrm{sec} ま て ゙$ 加速した. 30名の正常被検者に 対し線条視標とランダム視標による OKN を施行し， 小型電算機 PDP11/34を使用して分析した。

結果 正常被検者の線条刺澈 OKN では，ほぼ一定 の急速相振輻の眼振が眼前を通過する線条に一致して 発現した。一方，ランダム刺潡では多数の眼振が解発 され，眼振振幅は視標速度の増加にしたがって増加し た. 視標速度に対する緩徐相速度の利得は両刺激の間 で差がみられなかった. 眼振緩徐相速度と急速相速度 の相関関係をみると，ランダム刺激では両者の間に高
い相関が見られ，前庭性眼振と類似した反応態度を示 した。一方，線条刺激では全く相関性を示さない眼振 と相関性を示才眼振が混在し，前者の方が多数であっ た.これらの反応態度の差は低〜中視標速度で著明で あったが $70^{\circ} / \mathrm{sec}$ 以上の高速度では両者の差は不明確 であった。

結論 視運動性眼振の急速相の反応態度は線状刺激 とランダム刺激の視標形態によって異なることを示し た。線条刺激による視運動性眼振は，主に視標捕捉の 衝動性眼運動が眼振急速相を制御しているが，日常の 生理的な視刺激に類似したランダム刺激では主として 眼球偏位に対する立ち直り反射的な制御を受けると考 えられた，質問 和田 弘(日医大第 2). OKN O 注視型と，非注視型の具体的な万法について。応 答 線条刺激で眼前の視標を数えるように見るよう指 示，次に視標を変えランダム視標を線条視標と同しよ うに数えるような気持で見るように指示して検亘を行 った。質問 三好(南京都)。急速相速度は振幅と 相関が高いと思うが，その面からいかがか． 答 1) 線条刺激 OKN の振幅はほぼ一定であるが, 視標速 度の増加によりわずかに減少する.2）振幅をパラメーー タとすると明磪な傾向を把握することができないので 速度をパラメータにした。

\section{7. 中枢性平衡障害における視運動性眼振について \\ 一一振子様刺激と等加速度刺激の比較——}

\author{
小林英人・水越鉄理・渡辺行雄・大橋直樹（富山医薬大）
}

目的 私共は, 従来の等加速度 $\mathrm{OKN}$ 検査だけでな 〈振子様制激を用いた OKN (P.OKN) 検査も一連の 平衡機能検査システムとしてルーチンに行っている. 今回は中枢性平衡障害例を中心に，従来の等加速度刺 激による OKN 検査所見と対比し，P-OKN 検査の診 断学的意義について検討を加えた。

方法 1985年9月から1989年8月までの4年間比当 科を受診した中枢性平衡障害症例の中で障害部位の比 較的限局した194例を対象とした.その内訳は小脳障害 19例, 脳幹障害66例，小脳脳幹障害48例，小脸橋角部 腫湯36例, 资髄小脳変性症25例である。視運動性刺激
として左右水平方向に各々振幅 $120^{\circ}$, 周波数 $0.1 \mathrm{~Hz}$ の 振子様回転線条を投影し，同じ線条を用いた㐾来の等 加速度 $\mathrm{OKN}$ 検查所見と比較した。等加速度刺激は $\mathrm{CW}, \mathrm{CCW}$ とも角加速度 $1^{\circ} /$ 秒 $^{2}$ で 100 秒間の刺激を与 え，最大速度が $100^{\circ} /$ 秒になると線条の投光を停止し た、眼球運動の分析にはミニコンPDP11/34を使用し オンラインで処理した.

成績 中枢性平衡障害では，正常人に比心゙て POKN ゃ算加速度 OKN がともに抑制されている所見 が多くみられた.今回の症例をまとめてみると194例中 157 例 $(81 \%)$ の症例で P-OKN 検查の所胃と等加速度 